\title{
Comparison of anti-predatory defenses of Red Sea and Caribbean sponges. II. Physical defense
}

\author{
E. Burns, M. Ilan* \\ Department of Zoology, George S. Wise Faculty of Life Sciences, Tel Aviv University, Tel Aviv 69978, Israel
}

\begin{abstract}
In addition to the commonly used chemical defense mechanism against predation, sessile organisms such as terrestrial plants, soft corals and seaweeds are known to have a physical defense mechanism comprising structural elements made of lignin, $\mathrm{CaCO}_{3}$, silica, etc. Most sponges have siliceous spicules that play a key role as skeletal elements. To date, there has been no evidence to show that these spicules also play a role in defense against predation. It is known that low nutritional value of a prey may make it less susceptible to predation. The siliceous spicules found in sponges are indigestible to predators and so sponges that produce large amounts of these spicules may be less susceptible to predation due to their low nutritional value. In the present study, we tested the physical defenses of 6 Red Sea sponge species and 6 Caribbean sponge species against the generalist Red Sea wrasse Thalassoma klunzingeri. Physical defense of the 6 species collected in the Red Sea was also tested using the Caribbean wrasse T. bifasciatum. The spicules of 4 out of the 6 Red Sea sponges deterred predation by $T$. klunzingeri. Two out of the 6 Caribbean sponges were found to deter predation by $T$. klunzingeri. In assays conducted in the Bahamas on the Caribbean wrasse $T$. bifasciatum, only 1 Red Sea sponge species, Suberites clavatus, was found to be physically defended by its spicules. A positive correlation was found between the size of the spicules and their ability to deter predation by $T$. klunzingeri. Only spicules larger than $\sim 250 \mu \mathrm{m}$ deterred predation. On the other hand, $T$. bifasciatum seemed to be deterred based on reduced nutritional quality resulting from high concentration of spicules in a sponge, irrespective of their size. The combination of Crella cyatophora spicules and crude chemical extract deterred predation to a greater extent than that observed for each defense mechanism separately. This finding most probably indicates an additive mechanism of defense used by this sponge species.
\end{abstract}

KEY WORDS: Porifera · Physical defense · Spicules · Skeleton · Fish · Secondary metabolites Resale or republication not permitted without written consent of the publisher

\section{INTRODUCTION}

Members of the phylum Porifera (sponges) are a major component in many marine habitats, and in tropical coral reefs they often successfully rival corals in both abundance and diversity (Suchanek et al. 1983, Van Soest 1994). Tropical reefs are characterized by high levels of herbivory and predation (Hay 1991). Even so, not many organisms feed on sponges, and spongivory on tropical reefs is largely restricted to a few species of fish (Randall \& Hartman 1968, Wulff 1994), dorid nudibranchs (Todd 1981) and green and hawksbill turtles (Meylan 1988, Bjorndal 1990).
Sponges are sessile soft-bodied organisms that lack any obvious structural defense such as a shell or a hard exoskeleton. How, therefore, do these allegedly defenseless creatures defend themselves, and how is it possible for sponges to be so abundant in ecosystems in which predation pressure is so high? What defense mechanisms do sponges use to avoid or reduce predation? There is general agreement that chemical antipredatory defense mechanisms are important, i.e. production of deterrent secondary metabolites in the sponge tissues (e.g. Paul 1992, Pawlik et al. 1995). It would appear that the ability of sponges to defend themselves by chemical means plays an important role 
in controlling predator-prey relations and in the stabilization of marine populations (McClintock \& Baker 1997).

Another potential defense mechanism is by physical means. The physical defense theory holds that skeletal elements not only stabilize the structure of an organism, but can also play a role in its defense. The importance of physical defense for plants is well known and it includes lignified fibers (Coley 1983), resin and silica in terrestrial plants (Kaufman et al. 1981) and calcium carbonate $\left(\mathrm{CaCO}_{3}\right)$ in marine plants (Hay et al. 1994). Most sponges produce siliceous elements and organic fibers as structural elements. Sponges from the class Demospongiae (over $90 \%$ of all known sponge species) vary largely in their skeletal elements. Siliceous spicules in demosponges differ widely in size, shape and amount. Spongin fibers, too, differ in amount, thickness and density (Chanas \& Pawlik 1996). It has been shown that the spicules play a key role in supporting and stabilizing sponge tissue (Koehl 1982). There are many parallels between herbivory on terrestrial plants and marine spongivory. Both plants and sponges are abundant, diverse, conspicuous, lack behavioral defense and may bear both siliceous and refractory structural elements. Chanas \& Pawlik (1995, 1996) examined whether in sponges, as in plants, the siliceous elements and organic fibers play a role in defense against predation (Abrahamson 1989). They studied the contribution of spicules in such defense in 8 common Caribbean sponge species, rich in various types of spicules. Their results suggest that sponge spicules play no role in defense against predation, in either aquarium or field assays. In addition, it has been established that species which are not chemically defended (as shown in Pawlik et al. 1995) do not produce more spicules than species which are chemically defended. This absence of structural compensation for lack of chemical defense is in contrast to situations reported for tropical seaweed (Hay et al. 1988), gorgonians (Harvell \& Fenical 1989) and soft corals (Van Alstyne et al. 1994). Thus, unlike terrestrial plants which have biomineralized silica as both stabilizing and defense mechanisms (Abrahamson 1989), it was claimed that sponges use their siliceous spicules for structural support only (Chanas \& Pawlik 1995, 1996).

Studies which address the physical defense provided by soft coral sclerites (Van Alstyne \& Paul 1992, Van Alstyne et al. 1994, Koh et al. 2000), show that in some cases anti-predatory defense provided by the sclerites is at least as important as the chemical defense provided by secondary metabolites. According to Chanas \& Pawlik $(1995,1996)$, the deterrency of the spicules is not affected by the spicule type, orientation or concentration. More recently, O'Neal \& Pawlik (2002) found that only 2 of 32 species of Caribbean gorgonian corals tested contained sclerites that deterred predation. In contrast, Koh et al. (2000) showed that both the shape and concentration of the sclerites in a gorgonian coral influence their ability to deter predation.

Soft coral sclerites are much like demosponge spicules in shape and size but differ in composition: calcium carbonate in corals versus siliceous spicules in demosponges. It has been suggested that the defensive role of the calcified elements is also based on a chemical reaction in which dissolved $\mathrm{CaCO}_{3}$ alters the $\mathrm{pH}$ in the acidic gut of a predator (Hay et al. 1994). The siliceous spicules of sponges are chemically inert, and predators either avoid consuming them (Dayton et al. 1974, Pawlik 1983) or ingest them while they are still intact in their gut (Randall \& Hartman 1968, Meylan 1988).

Spicules make up the inorganic skeleton in the sponge while the organic skeleton is made up of spongin fibers. In a study conducted on Caribbean sponges, it was found that spicules could constitute up to $67.1 \%$ of total dry weight of the sponge (Rützler \& Macintyre 1978), while spongin fibers can constitute up to $\sim 30 \%$ of the sponge dry weight (Reiswig 1973). These fibers are resistant to enzymatic hydrolysis (Garrone 1978) and are therefore hard to digest (Bjorndal 1990). Since no evidence has been found to support the role of sponge spicules in defense against predation (Chanas \& Pawlik 1995, 1996), and because frequently most sponge mass consists of skeletal elements, researchers have assumed that the combination of large amounts of poorly digestible spongin and indigestible spicules lead to a considerable reduction in the nutritional quality of the sponges as prey, and thus result in the existence of only few sponge predators (Duffy \& Paul 1992, Chanas \& Pawlik 1996). Moreover, low nutritional quality increases the effectiveness of chemical defense (Duffy \& Paul 1992, Pennings et al. 1994).

We examined the existence of a physical defense mechanism in Red Sea sponges. We also studied the scope of the defense-general or specific for sympatric predators. The present study, together with that of Burns et al. (2003, this issue), presents the characterization of the defense mechanisms in Red Sea sponges. Using data regarding characteristic anti-predatory defense mechanisms in Caribbean sponges (reported in Pawlik et al. 1995 and Chanas \& Pawlik 1995, 1996), we can compare anti-predatory defense strategies used by sponges in these 2 geographically separate reef ecosystems.

\section{MATERIALS AND METHODS}

Sponge collection and identification. Sponges were collected in Elat, northern Red Sea, Israel, between 
October 2000 and April 2001 and from the Bahamas (during a research expedition on board RV 'Seward Johnson') during March 2001. Samples were collected separately from reefs while SCUBA diving and immediately stored at $-20^{\circ} \mathrm{C}$ for later use in subsequent extraction, biochemical analysis or isolation of spicules. Sponges were identified on the basis of their skeletal elements (Wiedenmayer 1977, Hartman 1982, Zea 1987).

Isolation of spicules. Spicules were isolated as described in Chanas \& Pawlik (1995). Sponge volume was measured by water displacement, followed by immersion in graduated $50 \mathrm{ml}$ centrifuge tubes filled with a $5.25 \%$ solution of sodium hypochlorite. After the solution stopped bubbling ( 1 to $3 \mathrm{~h}$ ), the supernatant was carefully decanted, and fresh solution was added. This process was repeated until the addition of fresh solution resulted in no further bubbling, and a mineral pellet of spicules was left on the bottom of the tube. After the final treatment, the solution was decanted and the pellet was washed with distilled water for a total of 3 rinses, 5 min each. Following the last rinse, the water was replaced with $70 \%$ ethanol for 10 to 15 min and after decanting the supernatant, the pellet was transferred to a pre-weighed vial and put in a hood to dry. When completely dry, the pellet was weighed to determine the natural volumetric concentration of the spicules in the sponge tissue. The mean spicule content of each sponge species was determined by obtaining spicules from 3 to 5 different sponges of each species.

Extraction. Sponge tissue was extracted as described in Pawlik et al. (1995). Frozen sponge tissue of known volume was chopped into $\sim \mathrm{cm}^{3}$ cubes and covered with a 1:1 mixture of dichloromethane and methanol in an erlenmeyer flask. The flask was kept chilled at $4{ }^{\circ} \mathrm{C}$ during a $24 \mathrm{~h}$ extraction period and was shaken every few hours. During this period, water was combined with the methanol, and the resulting methanol:water phase was separated from the dichloromethane phase. By shaking the flask periodically, the sponge tissue was alternately exposed to both phases. After extraction, both phases were filtered through filter paper (Whatman), evaporated to dryness on a rotary evaporator at low heat $\left(<50^{\circ} \mathrm{C}\right)$, and then combined. This process was repeated a second time. The remaining tissue was extracted a third time with methanol for 6 to $10 \mathrm{~h}$ at room temperature, and the resulting extract filtered, evaporated, and then combined with all prior extractions. The combined extracts yielded the crude extract, which was stored at $-20^{\circ} \mathrm{C}$ until further use.

Laboratory assays. Aquarium assays were performed as described in Pawlik et al. (1995) at the Interuniversity Institute (IUI) Marine Laboratory in Elat and on board RV 'Seward Johnson' in the Bahamas. Spicules obtained from 6 Red Sea sponge species were used in experiments held both in Elat and in the Bahamas: Axinella carteri, Diacarnus erethrianus, Crella cyatophora, Hemimycale sp., Niphates sp. and Suberites clavatus. Six Caribbean sponge species were used only in the experiments held at the IUI Marine Laboratory in Elat: Agelas clathrodes, Chondrilla nucula, Cribrochalina vasculum, Ectyoplasia ferox, Geodia neptuni and Stylissa sp. For each sponge species, a mixture of $0.3 \mathrm{~g}$ alginic acid and $0.5 \mathrm{~g}$ of freeze dried, powdered squid mantle, was added to a spicule weight adequate for $10 \mathrm{ml}$ live sponge tissue. Distilled water was added to yield a final volume of $10 \mathrm{ml}$. The mixture was gently stirred to avoid breakage of spicules until they were homogenously distributed in the alginic acid matrix. The mixture was then loaded into a $10 \mathrm{ml}$ syringe, the syringe tip was submerged in a $0.25 \mathrm{M}$ solution of calcium chloride, and the content of the syringe was emptied to form a long, spaghettilike strand. After a few minutes, the hardened strand was removed, rinsed in seawater, and cut into $3 \mathrm{~mm}$ long pellets using a razor blade. Control pellets were made the same way, but without the addition of spicules. The combined effect of chemical and physical defense was examined by preparing food pellets that contained $C$. cyatophora crude extract and spicules together, both in natural volumetric concentration. Control and treatment pellets were presented to groups of 2 to 3 Red Sea wrasses Thalassoma klunzingeri in experiments conducted in Elat and to groups of 3 or more Caribbean blue-headed wrasses T. bifasciatum in experiments conducted in the Bahamas. The fish groups were held in 10 separate, opaque-sided compartments in laboratory aquaria, as described in Pawlik et al. (1995). The 2 predator species are both very abundant generalist fishes, each in its natural reef. The merits of using $T$. bifasciatum in aquarium bioassays conducted in studies held in the Caribbean Sea have been previously described (Pawlik et al. 1987), as have the reasons for using a generalist fish, sensu Pawlik et al. (1995). In addition to T. klunzingeri being an abundant generalist fish in the reefs of the Red Sea, it was chosen for bioassays conducted in Elat in order to reduce to a minimum the potential variation in predator behavior due to taxonomic differences. The general biology (diet, habitat etc.) of the 2 species is very similar. Groups of fish were presented with a control pellet to ensure that the fish were hungry and cooperative. Fish that did not eat the control pellets did not participate in the experiment. After consuming the control pellet, the fish were presented with treated food pellets. If the pellet was rejected, another control pellet was offered to determine whether the fish had ceased feeding. A pellet was considered rejected if not 
eaten after a minimum of 3 attempts by 1 or more fish to take it into their mouth cavity, or if the pellet was approached and ignored after 1 such attempt. The significance of differences in the consumption of treated versus control pellets was evaluated using Fisher's exact test. For any single assay of 10 replicates, a treatment was considered as significantly deterrent if 4 or more pellets were rejected ( $\mathrm{p} \leq 0.043,1$-tailed test); therefore, in judging the mean deterrency of multiple samples from the same species, a treatment was considered deterrent if the mean number of pellets eaten was less than or equal to 6 .

Measuring spicule size. The size of 15 spicules of the most abundant spicule types was measured using a light microscope, and the mean length determined for each type of spicule.

\section{RESULTS}

\section{Deterrency of spicules}

The naturally occurring spicules of the 6 Red Sea sponge species tested for spicule deterrency differed in amount, size and morphology (Fig. 1). The spicules of 4 of the 6 species deterred predation of the Red Sea wrasse Thalassoma klunzingeri at natural concentration (Fig. 2). There was no obvious difference in the quantity of broken spicules between the different preparations. When tested on the naïve Caribbean wrasse $T$. bifasciatum, only the spicules of 1 Red Sea sponge, Suberites clavatus, deterred predation at a natural concentration (Fig. 3).

The 6 sponge species collected in the Bahamas also differed in the quantity of naturally occurring spicules in their body (Fig. 4). The spicules were tested for their contribution in deterring predation by the naïve Red

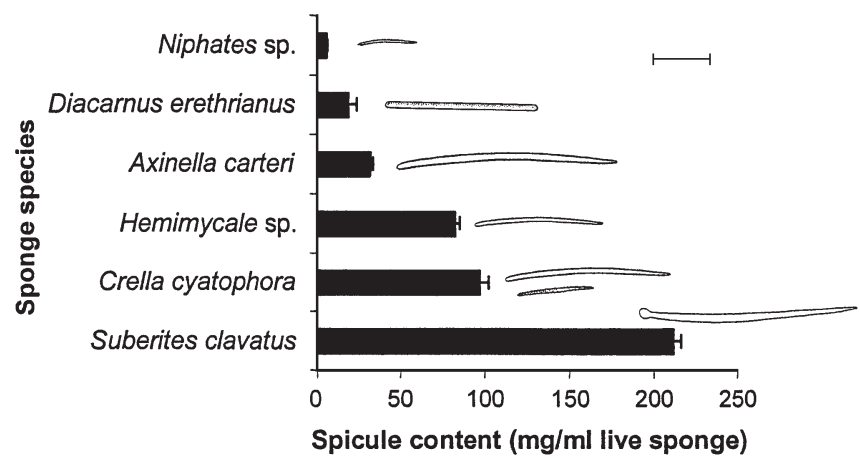

Fig. 1. Spicule content of 6 Red Sea sponges. Replicates for each sponge species is $n=5$. Drawings of representative spicule types are indicated next to the columns. All the spicules are drawn to the same scale $(100 \mu \mathrm{M})$

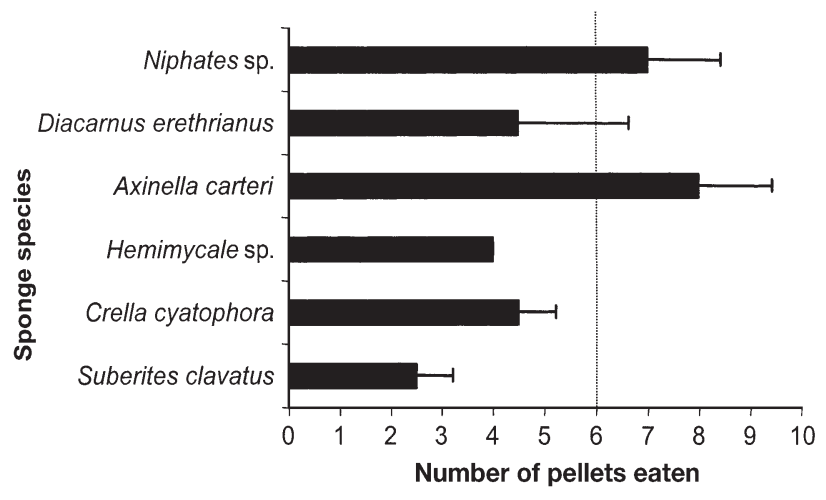

Fig. 2. Thalassoma klunzingeri. Consumption of food pellets (mean $+\mathrm{SD})$ containing sponges spicules at natural concentrations in aquarium assays. Fish consumed the 10 control pellets in all cases ( 2 replicate assays for every species). For any individual assay, spicules were considered deterrent if the number of pellets eaten was $\leq 6$ ( $p \leq 0.043$, Fisher's exact test, 1 -tailed) as indicated by the dotted line on the figure. The SD for Diacarnus erethrianus crosses the dotted line, but since each replicate yielded a significant result $(3 / 10$ and $6 / 10$ pellets eaten), we consider this result to be reliable

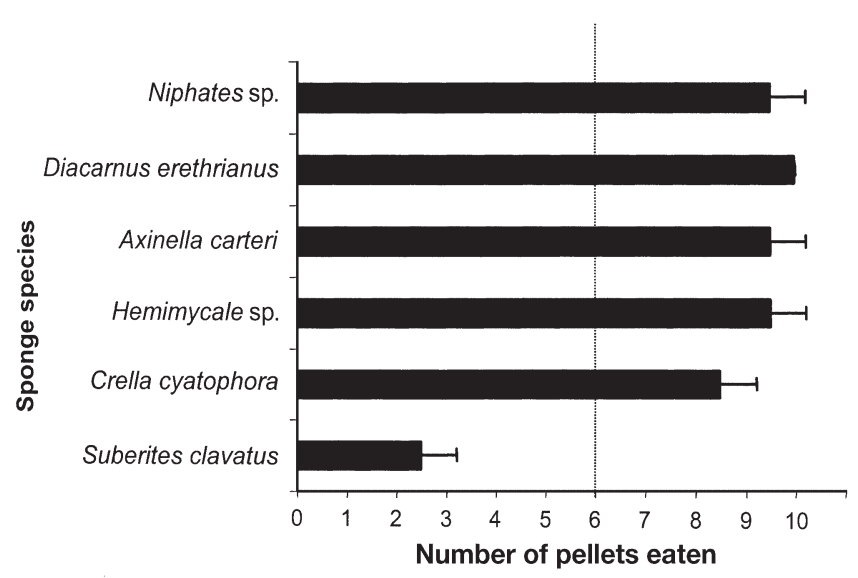

Fig. 3. Thalassoma bifasciatum. Consumption of food pellets (mean +SD) containing spicules of Red Sea sponges at natural concentrations in aquarium assays. Fish consumed the 10 control pellets in all cases (2 replicate assays for every species). For any individual assay, spicules were considered deterrent if the number of pellets eaten was $\leq 6$ ( $p \leq 0.043$, Fisher's exact test, 1-tailed) as indicated by the dotted line on the figure

Sea wrasse Thalassoma klunzingeri (Fig. 5). Food pellets containing spicules at natural volumetric concentration of 2 out of these 6 Caribbean sponge species, Chondrilla nucula and Geodia neptuni, were deterrent.

A positive correlation (Spearman correlation test, $\mathrm{p}=$ 0.046) was found between spicule size and their ability to deter predation by Thalassoma klunzingeri (Fig. 6). In the case of sponges with more than 1 type of spicule, 


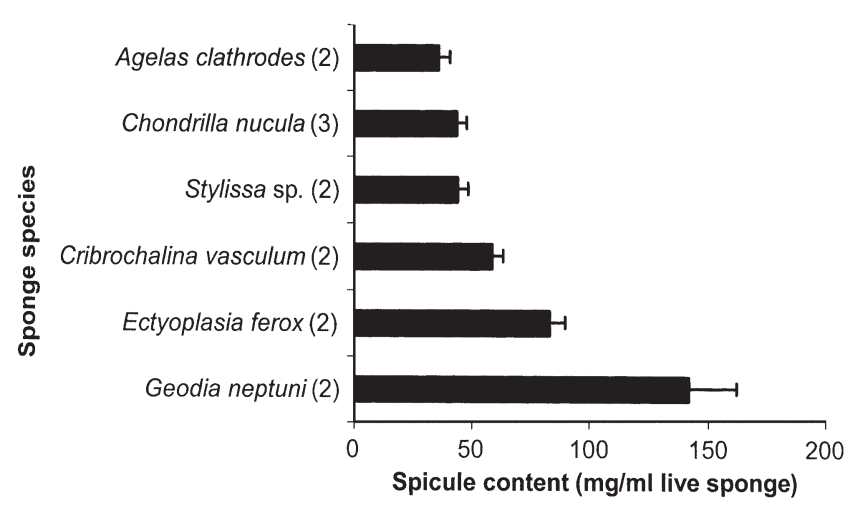

Fig. 4. Spicule content of 6 Caribbean sponges. The numbers of replicates follow each species name

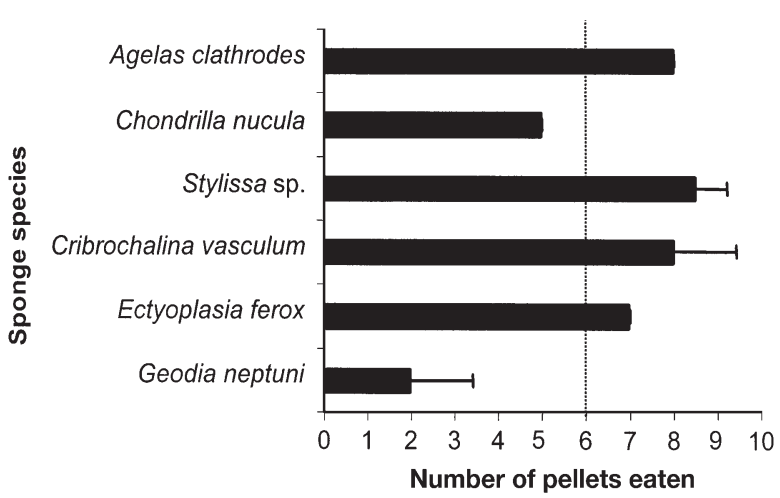

Fig. 5. Thalassoma klunzingeri. Consumption of food pellets $($ mean $+\mathrm{SD})$ containing spicules of Caribbean sponges at natural concentrations in aquarium assays. Fish consumed the 10 control pellets in all cases ( 2 replicate assays for every species). For any individual assay, spicules were considered deterrent if the number of pellets eaten was $\leq 6$ ( $p \leq 0.043$, Fisher's exact test, 1-tailed) as indicated by the dotted line on the figure

correlation was tested on the largest spicule type. No correlation was found between the natural concentration of spicules and their ability to deter predation by T. klunzingeri.

\section{Combined defenses}

The combined defense mechanisms of Crella cyatophora were tested against a naturally occurring predator, Thalassoma klunzingeri, and the naïve predator T. bifasciatum (Fig. 7). The combination of crude extract and spicules, both at natural volumetric concentrations, was significantly more deterrent than each treatment by itself, against both predator species ( $p<0.05$ in all cases, Mann-Whitney test).

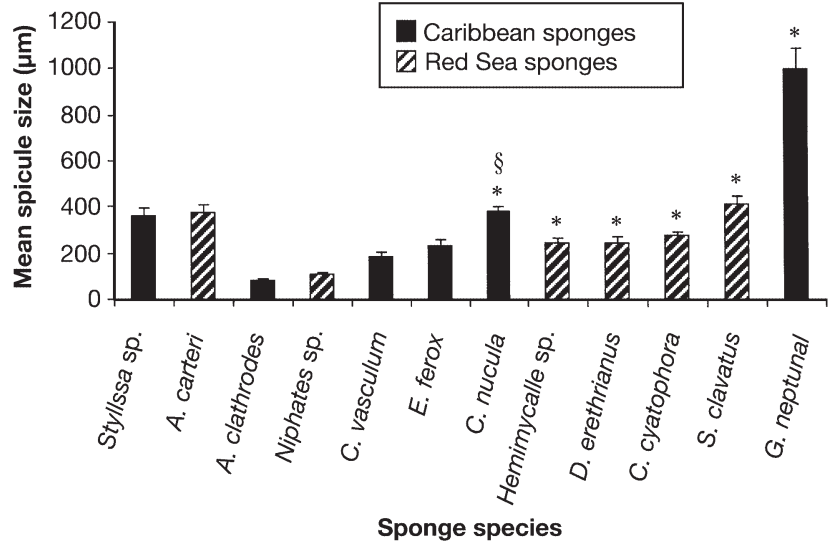

Fig. 6. Spicule size (mean $+\mathrm{SD})$. *: Sponges whose spicules deterred predation by Thalassoma klunzingeri at natural concentrations. For each sponge (for full species names see previous figures) correlation was tested on the largest spicule type. $\S$ : In order to avoid bias, the identification of spicule size and morphology (using a light microscope and suitable literature) characteristic to each sponge species was made only after conducting the laboratory assays. During these examinations, we detected that Chondrilla nucula spicules were contaminated with some large spicules (style, $381 \pm 23 \mu \mathrm{m}$ ). C. nucula is an encrusting sponge known to have only the spheraster type of spicules (Klautau et al. 1999). We assume that while collecting the sponge, a small piece from a different species, possibly the one C. nucula covered, was collected as well, and therefore spicules from both species were obtained

\section{DISCUSSION}

The presence of a chemical anti-predatory defense mechanism in sponges is well established (e.g. Paul 1992, Pawlik 1993, Pawlik et al. 1995, Burns et al. 2003). In contrast, the role of sponge structural elements (spicules and spongin fibers) in defense against predation is in doubt (Dayton et al. 1974, Pawlik 1983, Meylan 1988). Studies conducted in the Caribbean Sea provided no evidence for the existence of a physical defense mechanism in sponges (Chanas \& Pawlik 1995, 1996). Hill \& Hill (2002) suggested physical defense in the tropical sponge Anthosigmella varians but this was not demonstrated experimentally in feeding assays.

We present here the first study to show that in some sponge species, the spicules provide physical defense against predation by generalist fishes. Spicules in the sponges are usually organized in a particular manner. When incorporating spicules into the food pellets, they are randomly oriented. Our experiments test the effect of amount, size and shape of the spicules rather than the importance of their orientation. It should be noted that often naturally arranged spicules are perpendicular to the surface. When randomly arranged in food pellets, we expect that if the natural orientation of 


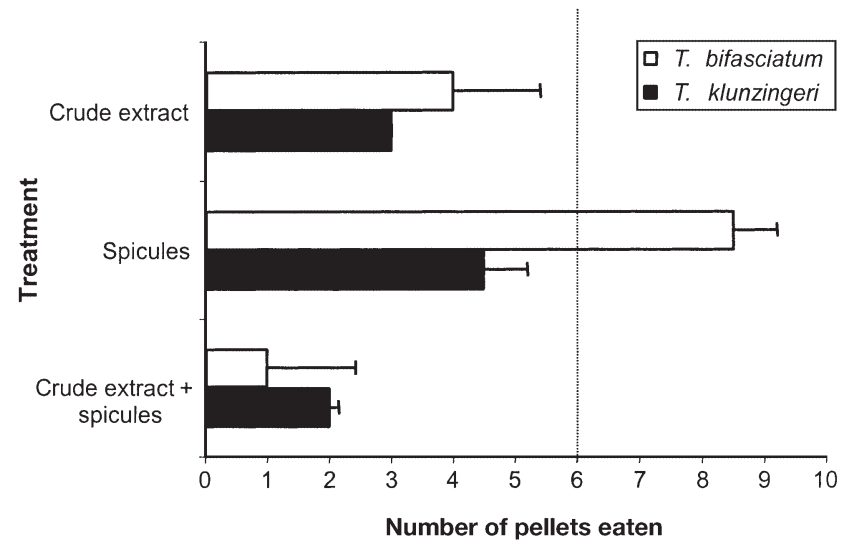

Fig. 7. Crella cyatophora. Assessment of spicules and chemical extract contribution in deterring Thalassoma klunzingeri and T. bifasciatum in aquarium assays. Consumption of food pellets (mean $+\mathrm{SD}$ ) containing sponge spicules and/or crude extract, both at natural concentrations. Fish consumed the 10 control pellets in all cases ( 2 replicate assays for every species). For any individual assay, spicules were considered deterrent if the number of pellets eaten was $\leq 6$ ( $p \leq 0.043$, Fisher's exact test, 1-tailed), as indicated by the dotted line on the figure. The results of the combined treatment are presented with the results shown before for each treatment alone

spicules has a defensive role it will be reduced, and if anything, we feel that a deterrent effect of spicules in our experiments lends further support to the existence of physical defense in nature.

Spicules at natural volumetric concentrations in 4 out of the 6 Red Sea sponge species tested deterred predation by the generalist Red Sea wrasse Thalassoma klunzingeri (Fig. 2). Spicules obtained from Red Sea sponges were also tested using the Caribbean wrasse T. bifasciatum, in order to determine whether the defense strategy is geographically specific or has a general effect towards allopatric predators as well. Only the spicules of 1 Red Sea sponge species, Suberites clavatus, deterred predation by T. bifasciatum at a natural concentration (Fig. 3).

Spicules obtained from 2 out of 6 Caribbean sponge species, Chondrilla nucula and Geodia neptuni, were deterrent when tested against the naïve Red Sea wrasse Thalassoma klunzingeri (Fig. 5). Five out of the 6 Caribbean sponge species used in this study (Agelas clathrodes, C. nucula, Cribrochalina vasculum, Ectyoplasia ferox and G. neptuni) were previously examined for spicule deterrency against $T$. bifasciatum (in aquarium assays) or against an assembly of naturally occurring reef predators (in field assays). In no case were the spicules deterrent (Chanas \& Pawlik 1995, 1996). As explained earlier, spicules obtained from $C$. nucula were contaminated with large spicules from an unknown source (see Fig. 6). In spite of the addition of spicules from the foreign source, the total amount of spicules obtained from C. nucula remained low (see Fig. 4), and so we can assume that it was the large spicules which caused the deterrence.

The Caribbean generalist predator was deterred neither by spicules occurring in Caribbean sponges which share its habitat, nor by spicules occurring in Red Sea sponges. Only the spicules of the Red Sea sponge Suberites clavatus (tylostyles) deterred predation by Thalassoma bifasciatum at a natural volumetric concentration. S. clavatus has the highest natural spicule concentration of all the Caribbean and Red Sea sponges tested in this study (Figs. 1 \& 4). This result complements the suggestion of Chanas \& Pawlik (1996) that it is not the spicules that deter predation by T. bifasciatum, but rather the diminishing value of the nutritional quality of the sponge as a prey. Chanas \& Pawlik (1996) showed that spicules from Caribbean sponges at natural concentrations deterred predation by $T$. bifasciatum only when incorporated into artificial food pellets that contained at least 5 times less protein than the average protein content in sponge tissue (as found in Chanas \& Pawlik 1995). This result was further supported when in additional studies protein content in artificial food pellets had the ability to influence predator consumption behavior (Duffy \& Paul 1992, Pennings et al. 1994). Duffy \& Paul (1992) showed that secondary metabolites deterred predation when inserted into artificial food pellets with low protein content, but were palatable when inserted into food pellets containing high protein content.

According to the 'low nutritional quality' theory, in order for spicules to deter predation by Thalassoma bifasciatum, their natural concentration should be high enough to radically reduce the nutritional quality of the sponge and make it an unattractive prey. It would appear that the extremely high concentration of spicules in Suberites clavatus is enough to reduce its nutritional quality to a level that makes it unattractive to predation by $T$. bifasciatum. As opposed to $T$. bifasciatum, which is not deterred by spicules as a physical defense mechanism at a natural concentration, a positive correlation was found between the size of the spicules and their ability to deter predation by the Red Sea T. klunzingeri. Sponges with at least 1 spicule type larger than $\sim 250 \mu \mathrm{m}$ deterred predation by $T$. kluzingeri, irrespective of geographic origin or total content within the sponge body (Fig. 6). During experiments, the fish immediately spat unpalatable pellets out. Sponges with all spicule types smaller than $\sim 250 \mu \mathrm{m}$ did not deter predation, even in cases where their natural spicule concentration was higher than in sponges with large spicules at a low natural concentration, which did deter predation. For example, the natural spicule concentration of Cribrochalina vasculum is higher than that of Diacarnus erethrianus (59.2 \pm 4.4 
vs $18.9 \pm 5.2 \mathrm{mg} \mathrm{ml}^{-1}$, respectively), but food pellets containing spicules of $C$. vasculum at a natural concentration were palatable (mean size of largest spicule type, strongyloxea: $186 \pm 5 \mu \mathrm{m}$ ), while food pellets containing spicules of $D$. erethrianus (mean size of largest spicule type, strongyle: $248 \pm 24 \mu \mathrm{m}$ ) at a natural concentration were deterrent. In both sponge species the spicules are a similar shape (monoactins).

The spicules of 2 sponge species, Axinella carteri from the Red Sea and Stylissa sp. from the Caribbean Sea, did not deter predation by Thalassoma Klunzingeri, even though they are larger than $250 \mu \mathrm{m}$ (378 \pm 29 and $365 \pm 30 \mu \mathrm{m}$, respectively). The reasons for this result are unclear, but it is interesting to note that these 2 species are systematically related and belong to the same family (Axinellidae). The 2 sponges are similar in shape and color, bear the same spicule type (style), and are of similar size.

The results of this study, together with results in Burns et al. (2003), suggest that predation behavior of the 2 wrasse species varies and could be attributed to different mechanisms. Most of the Caribbean reef sponge species examined by Pawlik et al. (1995) were found to be chemically defended, whereas less then half of the Red Sea sponges we examined (Burns et al. 2003) showed such defense. Thalassoma klunzingeri was found to be somewhat harder to deter than $T$. bifasciatum when testing consumption behavior using the same sponge extracts (Burns et al. 2003). Our finding that Red Sea sponges also use physical defense, in addition to their chemical defense, may be the result of Red Sea predators being harder to deter solely by chemical means. The theory offered by Chanas \& Pawlik (1996) regarding the predation behavior of $T$. bifasciatum responding to the nutritional quality of the prey does not explain the predation behavior of $T$. klunzingeri. With the exception of Suberites clavatus, all other Red Sea sponges whose spicules provided physical defense against predation by $T$. klunzingeri (Fig. 2) are poorer in spicule content than the Caribbean sponge Geodia neptuni, which is not physically defended against predation by $T$. bifasciatum. Therefore, when deterred by spicules, T. klunzingeri is deterred according to spicule size, even when they occur in low concentrations and do not significantly reduce the nutritional quality of the sponge tissue. This conclusion is reinforced by the results received when spicule deterrency of Caribbean sponges was examined against $T$. klunzingeri. Spicules obtained from Chondrilla nucula were deterrent. Even after the addition of spicules from a different sponge (spicule contamination, see above), the spicule concentration was the second lowest of all the Caribbean sponges tested (Fig. 4). On the other hand, it is the only Caribbean sponge in this study, other than G. neptuni (which pro- duces oxeas at an average size of $1004 \pm 88 \mu \mathrm{m}$ ), in which the samples used contained spicules larger than $250 \mu \mathrm{m}$. As explained before, these spicules are not produced by $C$. nucula and their origin is unclear, but their presence in the food pellets deterred predation by $T$. klunzingeri, as did the other food pellets containing large spicules.

Sponge (and soft coral) biomass is most prominent in the Caribbean Sea ecosystem, and is much greater than in the Red Sea. It is our assumption that this might be the evolutionary force that has led to the buildup of resistance to large sponge spicules in Caribbean predators. In the Red Sea, on the other hand, the variety of prey, other than sponges, is wide and therefore fishes may not have developed the ability to overcome sponge physical defense.

To rule out the possibility that naturally occurring low nutritional quality in the Red Sea sponge species is the reason for our findings, rather than genuine physical defense provided by spicules, we examined the Red Sea sponge Crella cyatophora for its natural protein and total energy content (protein content analysis followed Bradford 1976, and total energy content was determined using a Gollenkamp balistic bomb calorimeter). Low protein and/or total energy content could have given rise to uncertainty as to whether the spicules provide physical defense or whether they act as an additional factor in the reduction of the sponges' nutritional quality. The protein content of C. cyatophora was found to be $10.88 \pm 0.8 \mathrm{mg} \mathrm{ml}^{-1}$. Chanas \& Pawlik (1995) found the average protein content in 71 Caribbean sponge species to be $20.7 \pm 11.6 \mathrm{mg} \mathrm{ml}^{-1}$. In 11 of these species the protein content was lower than $10 \mathrm{mg} \mathrm{ml}^{-1}$. The total energy content of C. cyatophora was found to be $2.05 \pm 0.2 \mathrm{~kJ} \mathrm{ml}^{-1}$, whereas the average total energy of the 71 species examined by Chanas \& Pawlik (1995) was $2.0 \pm 0.9 \mathrm{~kJ} \mathrm{ml}^{-1}$. Thus, the protein and energy content found in C. cyatophora are no different from those found in Caribbean sponges. We suggest that in the Red Sea, spicules may provide antipredatory physical defense, based on spicule size, and do not act only as an additional factor in the reduction of sponge nutritional quality.

The combination of spicules and crude extract from Crella cyatophora (both at natural volumetric concentration), yielded food pellets significantly more deterrent than pellets containing each treatment separately (Fig. 7). This result was obtained in assays conducted on both the naturally occurring predator, Thalassoma klunzingeri and the allopatric predator, T. bifasciatum. The addition of spicules to the crude extract may elevate the effectiveness of the chemical defense due to lowering the nutritional value (as suggested by Duffy \& Paul 1992, Pennings et al. 1994). Another explanation may be that the spicules cause injury to the fishes' 
mouths. Such injury enables deterrent secondary metabolites to penetrate quickly into the predator's tissues, and thus act more efficiently. Chanas \& Pawlik (1996) showed that sponge tissue would have to be much lower in food value (5 times less protein or lower, in 3 common Caribbean sponge species tested) for spicules to provide an effective sole defense against Caribbean fish predators. Since the nutritional quality of $C$. cyatophora is average, and since the quantity of spicules produced by this sponge is not high enough to reduce the nutritional value of the sponge to a fifth of the average value, it seems that in this case the second explanation is the more probable. In the case of $T$. bifasciatum, the spicules alone do not deter predation (as opposed to deterring T. klunzingeri), but enhanced the effectiveness of the chemical defense. It is not uncommon for an organism to combine different defense mechanisms, either because 1 defense mechanism is not effective in deterring a wide array of predators (Paul \& Hay 1986, Hay et al. 1988) or because of energetic considerations (van Alstyne et al. 1994).

From a comparison of the existence of chemical and physical mechanisms, as found in this study and in Burns et al. (2003), it can be seen that of the 4 Red Sea sponge species that were physically defended by their spicules against predation by Thalassoma klunzingeri, only Crella cyatophora is also chemically defended. This result emphasizes the importance of the physical defense mechanism against predation in Red Sea sponges. The role of spicules is not only in supporting and stabilizing the sponge body, as previously thought. They can also play a key role in defense against predation in Red Sea sponges, whether combined with a chemical defense or as an effective defense mechanism in themselves. Contrary to C. cyatophora, which is the only sponge in this study with a combined chemical and physical defense mechanism, Niphates sp. stands out as a sponge that has neither of these 2 mechanisms (shown in Burns et al. 2003 and in this study). The 3 aspiculated sponge species tested by us for the existence of deterrent secondary metabolites were found to be palatable (Burns et al. 2003). Therefore, there appears to be no compensation by which Red Sea sponges that do not produce deterrent secondary metabolites will be physically defended, or vice versa. The question thus arises as to how such a 'defenseless' sponge survives in a reef environment where predation is so intense?

We suggest that the undefended sponge species channel more energy resources to rapid growth and reproduction than do other species. Indeed Niphates sp. has a long reproductive period of 9 mo and its larvae settle and undergo metamorphosis at high survival rates (Ilan \& Loya 1988). A study conducted on terrestrial plants shows that the growth rates of plants is in inverse proportion to the energy invested in defense (Coley et al. 1985). Pawlik (1997) also suggested that the rapid growth of Caribbean sponges which lack chemical defense may be sufficient to overcome the effects of predation. Another solution for survival of undefended sponges would be to grow in niches such as cracks and slits that are less accessible to most predators (Richter 2001). This study's results indicate that Pawlik's suggestion can be widened to include not only Caribbean sponges that lack chemical defense, but also Red Sea sponges that are neither chemically nor physically defended.

In previous studies researchers were surprised, given the parallels between herbivory on terrestrial plants and grazing on marine sponges, that there is good evidence of structural defense for plants but not for sponges (Chanas \& Pawlik, 1995, 1996). Here we present evidence that the parallels between terrestrial plants and marine sponges show similarities also with regard to the use of structural anti-predatory defense mechanisms. Not only plants, but Red Sea sponges too, can employ both chemical and structural defense tactics to reduce predation and survive.

Acknowledgements. We thank Prof. J. R. Pawlik for his valuable assistance along the way, Assaf Lipshitz for his help in executing the experiments in Elat, and Dovi Kelman for his support and ideas. We thank the captain and crew of the RV 'Seward Johnson' and the staff of the IUI Marine Laboratory in Elat for their hospitality and cooperation. We are grateful to the government of the Bahamas for permission to conduct research in their territorial waters.

\section{LITERATURE CITED}

Abrahamson WG (1989) Plant-animal interactions. McGrawHill, New York

Bjorndal KA (1990) Digestibility of the sponge Chondrilla nucula in the green turtle, Chelonia mydas. Bull Mar Sci 47:567-570

Bradford MM (1976) A rapid and sensitive method for the quantification of microgram quantities of protein utilizing the principle of protein-dye binding. Anal Biochem 72: 248-254

Burns E, Ifrach I, Carmeli S, Pawlik JR, Ilan M (2003) Comparison of anti-predatory defenses of Red Sea sponges and Caribbean sponges. I. Chemical defense. Mar Ecol Prog Ser 252:105-114

Chanas B, Pawlik JR (1995) Defenses of Caribbean sponges against predatory reef fish. II. Spicules, tissue toughness, and nutritional quality. Mar Ecol Prog Ser 127:195-211

Chanas B, Pawlik JR (1996) Does the skeleton of sponge provide a defense against predatory reef fish? Oecologia 107: 225-231

Coley PD (1983) Herbivory and defensive characteristics of tree species in a lowland tropical forest. Ecol Monogr 53: 209-233

Coley PD, Bryant JB, Chapin FS (1985) Resource availability and plant antiharbivore defense. Science 230:895-899 
Dayton PK, Robilliard GA, Paine RT, Dayton LB (1974) Biological accommodation in the benthic community at McMurdo Sound, Antarctica. Ecol Monogr 44:105-128

Duffy JE, Paul VJ (1992) Prey nutritional quality and the effectiveness of chemical defenses against tropical reef fishes. Oecologia 90:333-339

Garrone R (1978) Phylogensis of connective tissue. Karger, New York

Hartman WD (1982) Porifera. In: Parker SP (ed) Synopsis and classification of living organisms. McGraw-Hill, New York, p 640-666

Harvell CD, Fenical W (1989) Chemical and structural defenses of Caribbean gorgonians (Pseudopterogorgia spp.): intracolony localization of defense. Limnol Oceanogr 34: 382-389

Hay ME (1991) Fish-seaweed interactions on coral reefs, effects of herbivores fishes and adaptations of their pray. In: Sale PF (ed) The ecology of fishes on coral reefs. Academic Press, San Diego, CA, p 96-119

Hay ME, Kappel QE, Fenical W (1994) Synergisms in plant defenses against herbivores: interactions of chemistry, calcification and plant quality. Ecology 74:1714-1726

Hay ME, Paul VJ, Lewis SM, Gustafson K, Tucker J, Trindell RN (1988) Can tropical seaweeds reduce herbivory by growing at night? Diel patterns of growth, nitrogen content, herbivory and chemical versus morphological defenses. Oecologia 75:233-245

Hill MS, Hill AL (2002) Morphological plasticity in the tropical sponge Anthosigmella varians: responses to predators and wave energy. Biol Bull (Woods Hole) 202:86-95

Ilan M, Loya Y (1988) Reproduction and settlement of the coral reef sponge Niphates sp. (Red Sea). Proc 6th Int Coral Reef Symp 2:745-748

Kaufman PB, Dayanandan P, Takeoka Y, Bigelow WC, Jones JD, Iler R (1981) Silica in shoots of higher plants. In: Simpson TL, Volcani BE (eds) Silicon and siliceous structures in biological systems. Springer-Verlag, New York, p 409-450

Klautau M, Russo CA, Lazoski C, Boury-Esnault N, Thorpe JP, Sole-Cava M (1999) Does cosmopolitanism result from overconservative systematics? A case using the marine sponge Chondrilla nucula. Evolution 53:1414-1422

Koehl MAR (1982) Mechanical design of spicule-reinforced connective tissue: stiffness. J Exp Biol 98:239-267

Koh LL, Goh NKC, Chou LM, Tan YW (2000) Chemical and physical defenses of Singapore gorgonians (Octocorallia: Gorgonacea). J Exp Mar Biol Ecol 251:103-115

McClintock JB, Baker BJ (1997) A review of the chemical ecology of Antarctic marine invertebrates. Am Zool 37: $329-342$

Meylan A (1988) Spongivory in hawksbill turtles: a diet of glass. Science 239:393-395

O'Neal W, Pawlik JR (2002) A reappraisal of the chemical and physical defenses of Caribbean gorgonian corals against predatory fishes. Mar Ecol Prog Ser 240:117-126

Paul VJ (1992) Seaweed chemical defenses on coral reefs and chemical defenses of benthic marine invertebrates. In: Paul V (ed) Ecological roles of marine natural products. Comstock Publishing, Ithaca, NY

Paul VJ, Hay ME (1986) Seaweed susceptibility to herbivory:

Editorial responsibility: Otto Kinne (Editor),

Oldendorf/Luhe, Germany chemical and morphological correlates. Mar Ecol Prog Ser 33:225-264

Pawlik JR (1983) A sponge-eating worm from Bermuda: Branchiosyllis oculata (Polychaeta, Syllidae). PSZN I: Mar Ecol 4:65-79

Pawlik JR (1993) Marine invertebrate chemical defense. Chem Rev 93:1911-1922

Pawlik JR (1997) Fish predation on Caribbean reef sponges: an emerging perspective of chemical defense. In: Lessios HA, Macintyre IG (eds) Proc 8th Int Coral Reef Symp 2: 1255-1258

Pawlik JR, Burch MT, Fenical W (1987) Patterns of chemical defense among Caribbean gorgonian corals: a preliminary survey. J Exp Mar Biol Ecol 108:55-66

Pawlik JR, Chanas B, Toonen RJ, Fenical W (1995) Defenses of Caribbean sponges against predatory reef fish. I. Chemical deterrency. Mar Ecol Prog Ser 127:183-194

Pennings SC, Pablo SR, Paul VJ, Duffy JE (1994) Effects of sponge secondary metabolites in different diets on feeding by three groups of consumers. J Exp Mar Biol Ecol 180:137-149

Randall JE, Hartman WD (1968) Sponge feeding fishes of the West-Indies. Mar Biol 1:216-225

Reiswig HM (1973) Population dynamics of three Jamaican Demospongiae. Bull Mar Sci 23:191-226

Richter C, Wunsch M, Rasheed M, Kötter T, Badran MI (2001) Endoscopic exploration of Red Sea coral reefs reveals dense populations of cavity-dwelling sponges. Nature 413:726-730

Rützler K, Macintyre I (1978) Siliceous sponge spicules in coral reef sediments. Mar Biol 49:147-159

Suchanek TH, Carpenter RC, Witman JD, Harvell CD (1983) Sponges as important space competitors in deep Caribbean coral reef communities. In: Reaka ML (ed) The ecology of deep and shallow coral reefs. National Oceanic and Atmospheric Administration/NURP, Rockville, MD, p 55-59

Todd CD (1981) The ecology of nudibranch molluscs. Oceanogr Mar Biol Annu Rev 19:141-234

Van Alstyne KL, Paul VJ (1992) Chemical and structural defense in the sea fan Gorgonia ventalina: effects against generalist and specialist predators. Coral reefs 11:155-159

Van Alstyne KL, Wylie CR, Paul VJ (1994) Antipredator defenses in tropical Pacific soft corals (Coelentrata: Alcyonacea). II. The relative importance of chemical and structural defenses in the three species of Sinularia. J Exp Mar Biol Ecol 178:17-34

Van Soest RWM (1994) Demosponge distribution patterns. In: Van Soest RWM, Van Kempen TMG, Braekman JC (eds) Sponges in time and space. Balkema, Rotterdam, p 213-223

Wiedenmayer F (1977) Shallow-water sponges of the western Bahamas. Experientia Suppl 28. Birkhäuser Verlag, Stuttgart

Wulff JL (1994) Sponge feeding by Caribbean angelfishes, trunkfishes and filefishes. In: Van Soest RWM, Van Kempen TMG, Breakman JC (eds) Sponges in time and space. Balkema, Rotterdam, p 265-271

Zea S (1987) Esponjas del Caribe Colombiano. Editorial Catalogo Cientifico, Santa Marta

Submitted: October 22, 2002; Accepted: January 13, 2003 Proofs received from author(s): March 31, 2003 